\title{
Peningkatan Perhatian dan Hasil Belajar PKn Materi Budi Pekerti melalui Metode Pembelajaran Talking Stick (Penelitian Tindakan Kelas Pada Peserta Didik Kelas I Semester 2 SDN Ngiyono Tahun Pelajaran 2015/2016)
}

\author{
Mashadi* \\ ${ }^{1}$ SDN Ngiyono, Japah, Blora. Dinas Pendidikan Kabupaten Blora Propinsi \\ Jawa Tengah. Desa Ngiyono Kecamatan Japah Kabupaten Blora 58257, \\ Indonesia
}

*hadimas079@gmail.com

\begin{abstract}
The purpose of this study was to increase the attention and learning outcomes of PKN in the second semester students of class I on Budi Pekerti material at SD Negeri Ngiyono through the Talking Stick learning method for the 2015/2016 school year. This type of research is Class Action Research conducted in 2 cycles. Subjects of the study were class I students, amounting to 18 students consisting of 9 male students and 9 female students. Data collection methods used are observation, tests, and documentation. The results of the study showed an increase in the attention and learning outcomes of PKN students. This is shown from the pre cycle average value of attention and learning outcomes of students is 71.11 with a percentage of completeness of $35.00 \%$ which reaches the value of completeness. In the first cycle the average value of attention and learning outcomes of students is 79.44 with the percentage of completeness $68.00 \%$ while in the second cycle the average value of attention and learning outcomes of students is 88.33 with a percentage of $96.00 \%$ completeness. Attention and learning outcomes of students on PKN subjects Budi Pekerti material in class I semester 2 increased with the application of Talking Stick learning methods and has met the indicator of success that is equal to $75 \%$.
\end{abstract}

\begin{abstract}
Abstrak. Tujuan penelitian ini adalah untuk meningkatkan perhatian dan hasil belajar PKN peserta didik kelas I semester 2 pada materi Budi Pekerti di SD Negeri Ngiyono melalui metode pembelajaran Talking Stick tahun pelajaran 2015/2016. Jenis penelitian adalah Penelitian Tindakan Kelas yang dilaksanakan dalam 2 siklus Subyek penelitian adalah peserta didik kelas I yang berjumlah 18 peserta didik yang terdiri dari 9 peserta didik laki-laki dan 9 peserta didik perempuan. Metode pengumpulan data yang digunakan adalah observasi, tes, dan dokumentasi. Hasil penelitian menunjukkan adanya peningkatan perhatian dan hasil belajar PKN peserta didik. Hal ini ditunjukkan dari pra siklus rata-rata nilai perhatian dan hasil belajar peserta didik adalah 71,11 dengan persentase ketuntasan 35,00\% yang mencapai nilai ketuntasan. Pada siklus I rata-rata nilai perhatian dan hasil belajar peserta didik adalah 79,44 dengan persentase ketuntasan $68,00 \%$ sedangkan pada siklus II rata-rata nilai perhatian dan hasil belajar peserta didik adalah 88,33 dengan persentase ketuntasan 96,00\%. Perhatian dan hasil belajar peserta didik pada mata pelajaran PKN materi Budi Pekerti di kelas I semester 2 meningkat dengan penerapan metode pembelajaran Talking Stick dan telah memenuhi indikator keberhasilan yaitu sebesar $75 \%$.
\end{abstract}

Kata kunci: Talking Stick, perhatian belajar, PKN, materi Budi Pekerti 


\section{Pendahuluan}

Dalam proses pembelajaran bukan hanya pemahaman kognitif yang diperlukan tetapi juga afektif dan psikomotorik. Terutama di sekolah dasar segalam macam pembelajaran ataupun setiap mata pelajaran harus ada ketiga unsur tersebut yaitu kognitif, afektif, dan psikomotorik. Dengan ketiga unsur tersebut nantinya dapat membantu peserta didik ketiga berada di lingkungan masyarakat. Pembelajaran PKn mempunyai peran yang sangat penting. Mata pelajaran PKn diharapkan akan mampu membentuk peserta didik yang ideal memiliki mental yang kuat, sehingga dapat mengatasi permasalahan yang akan dihadapi. Begitu pentingnya pembelajaran PKn di sekolah terutama di sekolah dasar karena merupakan pendidikan dasar bagi peserta didik sebelum ke jenjang pendidikan yang lebih tinggi. Pada saat peserta didik mengikuti pelajaran di kelas diharapkan peserta didik untuk ikut aktif dalam proses pembelajaran, dengan demikian peserta didik akan mudah untuk memahami dan mengerti materi yang disampaikan oleh guru. "Dalam standar isi 2006 dijelaskan bahwa Mata Pelajaran Pendidikan Kewarganegaraan merupakan mata pelajaran yang memfokuskan pada pembentukan warga negara yang memahami dan mampu melaksanakan hak - hak dan kewajibannya untuk menjadi warga negara Indonesia yang cerdas, terampil, dan berkarakter yang diamanati oleh Pancasila dan UUD 1945" [2].

Mengungkapkan perhatian adalah perumusan tenaga psikis yang tertuju pada suatu objek, atau banyak sedikitnya kesadaran yang menyertai sesuatuaktivitas yang dilakukan [4]. Perhatian adalah merupakan salah satu faktor psikologis yang dapat membantu terjadinya interaksi dalam proses belajar mengajar [6]. Perhatian adalah proses mental ketika stimuli atau rangkaian stimuli menjadi menonjol dalam kesadaran pada saat stimuli melemah [5]. Perhatian terjadi bila kita mengkonsentrasikan diri pada salah satu alat indera kita, dan mengesampingkan masukan-masukan melalui alat indera yang lain.

Tetapi kenyataan di lapangan banyak sekali hal yang bertolak belakang dengan apa yang telah dipaparkan penulis. Berdasarkan hasil observasi pra siklus peserta didik kelas I SD Negeri Ngiyono pada pembelajaran PKN diperoleh perhatian dan hasil belajar PKN peserta didik yang masih rendahPada kegiatan observasi pra siklus jumlah peserta didik yang tuntas KKM hanya mencapai 10 peserta didik dari 25 peserta didik dengan rata-rata nilai 71,20 dan persentase ketuntasan 40,00\%. Selain hal itu, aktivitas belajar peserta didik terasa membosankan dan tidak menarik untuk peserta didik belajar. Sehingga perhatian peserta didik terhadap pembelajaran menjadi berkurang yang akhirnya hasil belajar peserta didik pun juga berkurang atau rendah. Hasil belajar adalah hasil yang diperoleh seseorang peserta didik untuk mengetahui sejauh mana bahan pelajaran atau materi yang diajarkan yang sudah diterima oleh peserta didik" [1]. Hasil belajar merupakan hasil dari suatu interaksi tindak belajar dan tindak mengajar." Dari sisi guru tindak mengajar diakhiri dengan proses evaluasi hasil belajar. Dari sisi peserta didik hasil belajar merupakan berakhirnya puncak proses belajar [3].

Salah satu metode pembelajaran yang sesuai dan menarik bagi peserta didik di kelas I adalah metode pembelajaran Talking Stick. Metode pembelajaran Talking Stick adalah sebuah metode pembelajaran yang menggunakan tongkat yang tidak terlalu panjang, tongkat tersebut diputar kesemua peserta didik sambil menyanyikan sebuah lagu. Metode pembelajaran Talking Stick adalah metode pembelajaran yang sangat menyenangkan maupun menegangkan bagi peserta didik karena harus siap dan secara mendadak menjawab pertanyaan dari guru. Maka dari itu semua peserta didik diharapkan untuk memahami dan memperhatikan selalu penjelasan guru.

Berasarkan latar belakang tersebut di atas maka dapat dirumuskan permasalahan yaitu apakah penerapan metode pembelajaran Talking Stick dapat meningkatkan perhatian belajar peserta didik pada mata pelajaran PKN materi Budi Pekerti peserta didik kelas I semester 2 di SD Negeri Ngiyono pada tahun pelajaran 2015/2016 serta apakah penerapan metode pembelajaran Talking Stick dapat meningkatkan hasil belajar peserta didik pada mata pelajaran PKN materi Budi Pekerti peserta didik kelas I semester 2 di SD Negeri Ngiyono pada tahun pelajaran 2015/2016?. Tujuan dari penelitian ini adalah Untuk mengetahui 
penerapan metode pembelajaran Talking Stick terhadap peningkatan perhatian dan hasil belajar PKN peserta didik kelas I smester 2 pada materi Budi Pekerti di SD Negeri Ngiyono.

\section{Metode}

Jenis penelitian yang digunakan adalah penelitian kualitatif. Penelitian kualitatif merupakan suatu penelitian yang menghasilkan data deskriptif (kata-kata tertulis/lisan dari orang-orang yang diamati) dan digunakan untuk meneliti kondisi alamiah [7]. Penelitian kualitatif ini menggunakan desain Penelitian Tindakan Kelas (PTK). Penelitian tindakan kelas adalah suatu bentuk pencermatan dari kegiatan pembelajaran yang dilakukan di dalam kelas untuk meningkatkan suatu hal di mana guru telah menentukan fokus permasalahan, tindakan yang harus dilakukan, dan menentukan tingkat keberhasilan dari tindakan tersebut [7]. Penelitian Tindakan Kelas (PTK) dilaksanakan dalam beberapa siklus dan setiap siklus terdiri dari empat tahapan yaitu perencanaan (planning), pelaksanaan tindakan (action), pengamatan (observation), dan refleksi (reflection). Subjek penelitian dibagi menjadi dua, sebagai berikut : subjek pelaku tindakan yaitu guru sebagai peneliti dan subjek penerima tindakan adalah peserta didik kelas I SD Negeri Ngiyono Tahun Pelajaran 2015/2016 dengan jumlah peserta didik 18 yang terdiri dari 9 peserta didik laki-laki dan 9 peserta didik perempuan.

\section{Hasil Pembahasan}

Dari hasil penilaian perhatian dan hasil belajar peserta didik yang dilakukan sebelum pelaksanaan siklus (pra siklus) pada pembelajaran PKN kelas I semester 2 materi Budi Pekerti diketahui bahwa persentase ketuntasan baru sekitar 35,00\% atau hanya 6 peserta didik saja yang tuntas dari 18 peserta didik di kelas I SD Negeri Ngiyono. Dan rata-rata nilai perhatian dan hasil belajar PKN peserta didik sebelum tindakan adalah 71,11. Untuk lebih jelasnya dapat dilihat pada tabel dbawah ini.

Tabel 1.Hasil Belajar PKN Peserta didik Kelas I Materi Budi Pekerti Pra Siklus

\begin{tabular}{ccccl}
\hline NO & NAMA & KKM & NILAI & KETERANGAN \\
\hline 1 & A & 75 & 70 & Belum Tuntas \\
2 & B & 75 & 60 & Belum Tuntas \\
3 & C & 75 & 80 & Tuntas \\
4 & D & 75 & 70 & Belum Tuntas \\
5 & E & 75 & 80 & Tuntas \\
6 & F & 75 & 70 & Belum Tuntas \\
7 & G & 75 & 90 & Tuntas \\
8 & H & 75 & 60 & Belum Tuntas \\
9 & I & 75 & 50 & Belum Tuntas \\
10 & J & 75 & 50 & Belum Tuntas \\
11 & K & 75 & 100 & Tuntas \\
12 & L & 75 & 70 & Belum Tuntas \\
13 & M & 75 & 60 & Belum Tuntas \\
14 & N & 75 & 90 & Tuntas \\
15 & O & 75 & 70 & Belum Tuntas \\
16 & P & 75 & 70 & Belum Tuntas \\
17 & Q & 75 & 80 & Tuntas \\
18 & R & 75 & 60 & Belum Tuntas \\
\hline & JUMLAH & & 1280 & \\
& RATA-RATA & 71,11 & \\
& KETUNTASAN KLASIKAL & & $35,00 \%$ & \\
\hline
\end{tabular}


Dari tabel di atas dapat digambarkan dengan grafik di bawah ini

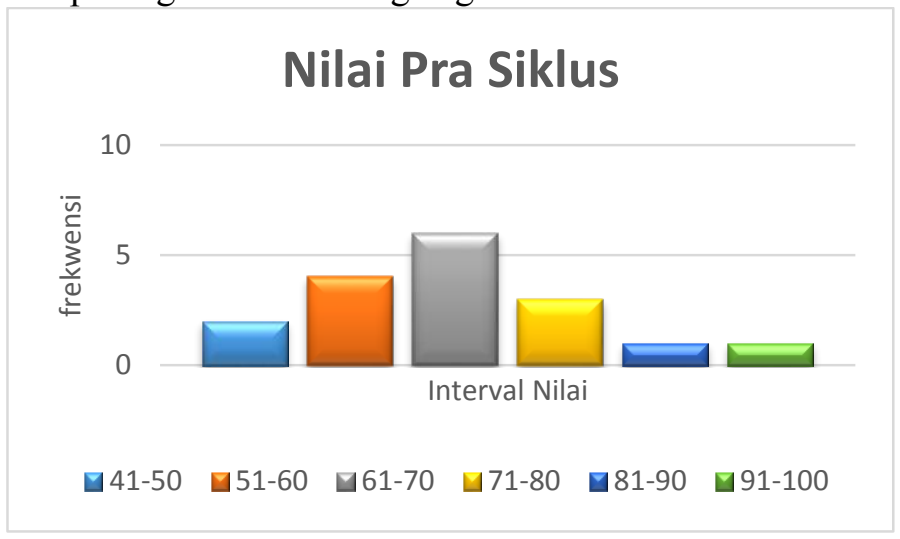

Gambar 1. Grafik Frekuensi Hasil Belajar PKN Peserta didik Kelas I Materi Budi Pekerti Sebelum Tindakan (Pra Siklus)

Dari penilaian perhatian dan hasil belajar PKN peserta didik kelas I semester 2 materi Budi Pekerti yang dilakukan sebelum pelaksanaan siklus (pra siklus) diketahui bahwa hasilnya masih sangat rendah. Dari hasil analisis dan hasil observasi siklus I diperoleh persentase ketuntasan perhatian dan hasil belajar kelas I semester 2 pada pembelajaran PKN materi Budi Pekerti adalah 68,00\% atau hanya 12 peserta didik yang mencapai nilai ketuntasan. Dan rata-rata nilai perhatian dan hasil belajar kelas I semester 2 pada pembelajaran PKN materi Budi Pekerti pada kegiatan siklus I adalah 79,44. Dan terjadi peningkatan perhatian dan hasil belajar peserta didik kelas I semester 2 pada pembelajaran PKN materi Budi Pekerti dari pra siklus ke siklus I sebesar $33,00 \%$.

Tabel 2

Hasil Belajar PKN Peserta didik Kelas I Materi Budi Pekerti siklus I

\begin{tabular}{ccccl}
\hline NO & NAMA & KKM & NILAI & KETERANGAN \\
\hline 1 & A & 75 & 80 & Tuntas \\
2 & B & 75 & 70 & Belum Tuntas \\
3 & C & 75 & 90 & Tuntas \\
4 & D & 75 & 80 & Tuntas \\
5 & E & 75 & 80 & Tuntas \\
6 & F & 75 & 80 & Tuntas \\
7 & G & 75 & 100 & Tuntas \\
8 & H & 75 & 70 & Belum Tuntas \\
9 & I & 75 & 60 & Belum Tuntas \\
10 & J & 75 & 50 & Belum Tuntas \\
11 & K & 75 & 100 & Tuntas \\
12 & L & 75 & 80 & Tuntas \\
13 & M & 75 & 70 & Belum Tuntas \\
14 & O & 75 & 100 & Tuntas \\
15 & P & 75 & 80 & Tuntas \\
16 & Q & 75 & 80 & Tuntas
\end{tabular}




\begin{tabular}{cccll}
17 & $\mathrm{R}$ & 75 & 90 & Tuntas \\
18 & $\mathrm{~S}$ & 75 & 70 & Belum Tuntas \\
\hline \multicolumn{3}{c}{ JUMLAH } & 1430 & \\
& & 79,44 & \\
& RATA-RATA & & \\
& KETUNTASAN KLASIKAL & & \\
\hline
\end{tabular}

Berdasarkan tabel di atas maka dapat digambarkan ke dalam grafik seperti di bawah ini :

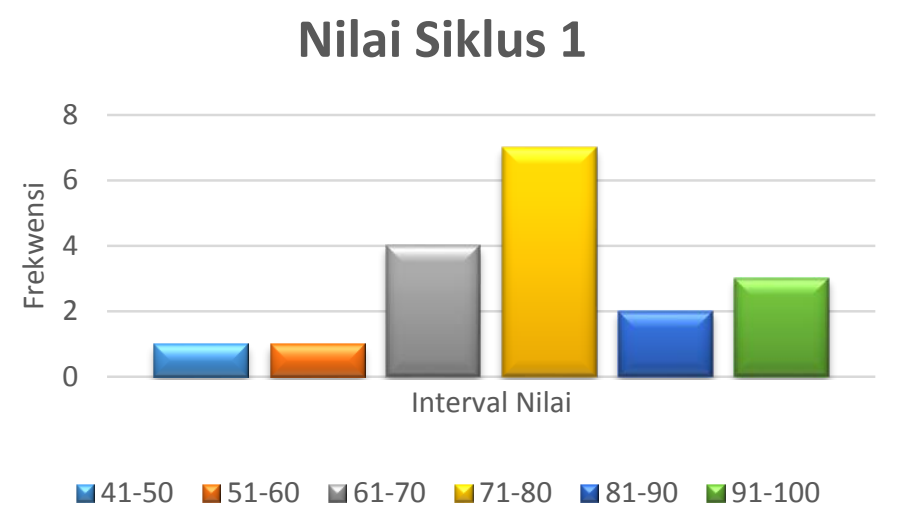

Gambar 2.Grafik Frekuensi Hasil Belajar PKN Peserta didik Kelas I Materi Budi Pekerti Siklus I

Dari hasil analisis dan hasil observasi siklus II diperoleh persentase ketuntasan perhatian dan hasil belajar kelas I semester 2 pada pembelajaran PKN materi Budi Pekerti adalah $96,00 \%$ atau 17 peserta didik yang mencapai nilai ketuntasan. Dan rata-rata nilai perhatian dan hasil belajar kelas I semester 2 pada pembelajaran PKN materi Budi Pekerti pada kegiatan siklus II adalah 88,33. Dan terjadi peningkatan perhatian dan hasil belajar peserta didik kelas I semester 2 pada pembelajaran PKN materi Budi Pekerti dari siklus I ke siklus II sebesar $28,00 \%$.

Tabel 3

Hasil Belajar PKN Peserta didik Kelas I Materi Budi Pekerti Siklus II

\begin{tabular}{ccccl}
\hline NO & NAMA & KKM & NILAI & KETERANGAN \\
\hline 1 & A & 75 & 80 & Tuntas \\
2 & B & 75 & 80 & Tuntas \\
3 & C & 75 & 100 & Tuntas \\
4 & D & 75 & 80 & Tuntas \\
5 & E & 75 & 90 & Tuntas \\
6 & F & 75 & 90 & Tuntas \\
7 & G & 75 & 100 & Tuntas \\
8 & H & 75 & 80 & Tuntas \\
9 & I & 75 & 80 & Tuntas \\
10 & J & 75 & 80 & Tuntas \\
11 & K & 75 & 100 & Tuntas \\
12 & L & 75 & 90 & Tuntas \\
13 & M & 75 & 90 & Tuntas \\
14 & N & 75 & 100 & Tuntas
\end{tabular}




\begin{tabular}{ccccl}
15 & $\mathrm{O}$ & 75 & 90 & Tuntas \\
16 & $\mathrm{P}$ & 75 & 90 & Tuntas \\
17 & $\mathrm{Q}$ & 75 & 100 & Tuntas \\
18 & $\mathrm{R}$ & 75 & 70 & Belum Tuntas \\
\hline & JUMLAH & 1590 & \\
& RATA-RATA & 88,33 & \\
& KETUNTASAN KLASIKAL & $96,00 \%$ & \\
\hline
\end{tabular}

Berdasarkan tabel 3 di atas maka dapat digambarkan ke dalam grafik seperti di bawah ini :

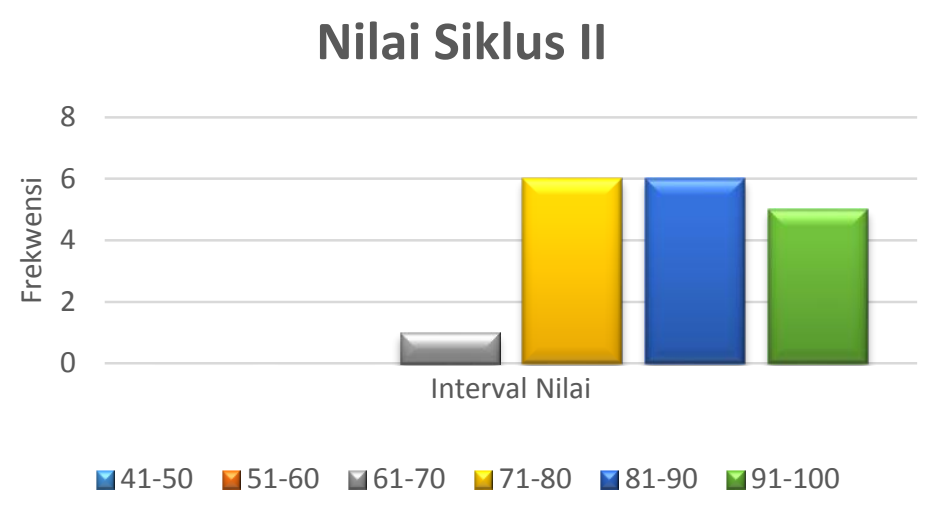

Gambar 3.Grafik Frekuensi Hasil Belajar PKN Peserta didik Kelas I Materi Budi Pekerti Siklus II

Berdasarkan data dari pra siklus, siklus I, dan siklus II dapat diketahui bahwa setiap siklus mengalami peningkatan. Dan dari data yang diperoleh dari siklus II persentase perhatian dan hasil belajar peserta didik kelas I semester 2 pada pembelajaran PKN materi Budi Pekerti di SD Negeri Ngiyono adalah $96,00 \%$ sudah memenuhi indikator keberhasilan yaitu sebesar $75 \%$. Untuk lebih jelasnya dapat dilihat pada tabel 4 .

Tabel 4.Perbandingan Ketuntasan Pra Siklus, Siklus I Dan Siklus II

\begin{tabular}{lccc}
\hline & PRA & & SIKLUS \\
NILAI & SIKLUS & SIKLUS I & II \\
\hline $41-50$ & 2 & 1 & 0 \\
$51-60$ & 4 & 1 & 0 \\
$61-70$ & 6 & 4 & 1 \\
$71-80$ & 3 & 7 & 6 \\
$81-90$ & 1 & 2 & 6 \\
$91-100$ & 1 & 3 & 5 \\
\hline
\end{tabular}

Berdasarkan tabel 4 di atas maka dapat digambarkan ke dalam grafik seperti di bawah ini : 


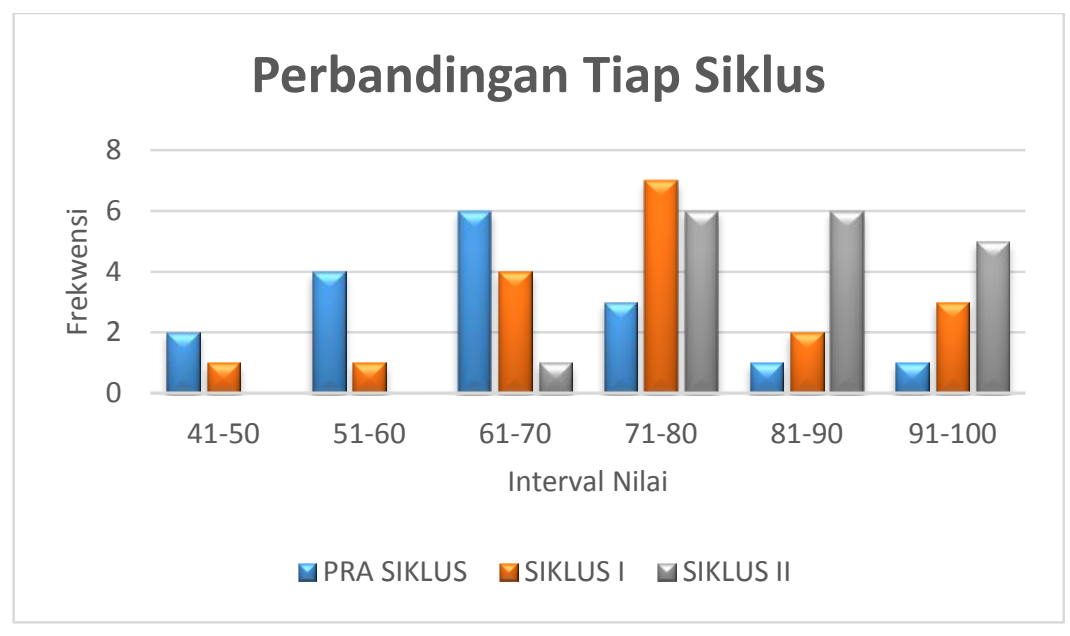

Gambar 4. Grafik Perbandingan Ketuntasan Pra Siklus, Siklus I Dan Siklus II

\section{Kesimpuan}

Hasil penelitian tindakan kelas yang dilakukan dapat disimpulkan bahwa penerapan pendekatan metode pembelajaran Talking Stick dapat meningkatkan perhatian dan hasil belajar peserta didik kelas I semester 2 pada pembelajaran PKN materi Budi Pekerti di SD Negeri Ngiyono tahun pelajaran 2015/2016. Hal ini dapat dilihat dari indikator keberhasilan yang diamati telah mencapai target yaitu sebesar $96,00 \%$ serta hasil penelitian dapat disimpulkan bahwa terjadi peningkatan rata-rata hasil belajar peserta didik kelas I semester 2 pada pembelajaran PKN materi Budi Pekerti dari rata-rata nilai dasar 71,11 naik menjadi 79,44 pada siklus I dan 88,33 pada siklus II. Dilihat dari rata-rata kenaikan pada setiap siklus maka dapat dikatakan bahwa persentase peningkatan dari pra siklus $35,00 \%$ naik menjadi $68,00 \%$ pada siklus I, dan naik menjadi 96,00\% pada siklus II.

\section{References}

[1] Arikunto, Suhasimi. 2001. Prosedur Penelitian, Suatu Pendekatan Praktek. Jakarta: Bina Aksara

[2] Depdiknas. 2006. Permendiknas No 22 thun 2006 Tentang Standar Isi. Jakarta:Depdiknas

[3] Dimyati dan Mudjiono. 2006. Belajar dan Pembelajaran. Jakarta : PT Rineke Cipta

[4] Sumadi Suryabrata, 1998. Psikologi Pendidikan . Jakarta:PT Raja Grafindo Persada

[5] Rakhmat, Jalaludin, 2000. Metode Penelitian Komunikasi. Bandung: PT Remaja Rosdakarya

[6] Ramayulis. 1994. Ilmu Pendidikan Islam. Jakarta: Kalam Mulia

[7] Rubiyanto. 2011. Metode Penelitian Pendidikan. Surakarta:PSKGJ FKIP UMS 